SUTASOMA
Jurnal Sastra Jawa
Sttps://journal.unnes.ac.id/sju/index.php/sutasoma

\title{
Istilah-Istilah Sesaji Ritual Sedekah Gunung Merapi di Desa Lencoh, Kecamatan Selo, Kabupaten Boyolali (Kajian Etnolinguistik)
}

\author{
Suci Makrifah ${ }^{1}$, Nur Fateah, S.Pd.,M.A. ${ }^{2}$ \\ 1,2Jurusan Bahasa dan Sastra Jawa, Fakultas Bahasa dan Seni, Universitas Negeri Semarang, Indonesia \\ Corresponding Author: sucimakrifah03@gmail.com
}

\begin{abstract}
Abstrak
Penelitian ini mendiskusikan istilah-istilah sesaji ritual sedekah Gunung Merapi di Desa Lencoh, Kecamatan Selo, Kabupaten Boyolali. Tujuan penelitian adalah: (1) untuk mendeskripsikan bentuk istilah-istilah sesaji ritual sedekah Gunung Merapi di Desa Lencoh Boyolali; (2) untuk memaparkan makna leksikal dan makna kultural istilah-istilah sesaji ritual sedekah Gunung Merapi di Desa Lencoh, Boyolali; (3) untuk menjelaskan cerminan kearifan lokal dalam istilah-istilah sesaji ritual sedekah Gunung Merapi di Desa Lencoh, Boyolali. Pendekatan yang digunakan adalah pendekatan etnolinguistik dan deskriptif kualitatif. Data dalam penelitian dikumpulkan dengan menggunakan metode etnografi dengan teknik observasi dan wawancara. Analisis data menggunakan metode distribusional, metode padan, dan etnosains terhadap istilah-istilah sesaji ritual sedekah gunung. Hasil penelitian menunjukkan bahwa: 1) bentuk istilah-istilah sesaji ritual sedekah Gunung Merapi terdiri atas kata dan frasa; 2) istilah-istilah sesaji ritual sedekah Gunung Merapi diklasifikasikan berdasarkan makna leksikal dan makna kultural; dan 3) kearifan lokal yang ditemukan pada ritual sedekah Gunung Merapi merupakan kearifan kutural yang diperoleh melalui pengalaman hidup dan atau diwariskan secara turun-temurun sebagai pedoman dalam berkegiatan.
\end{abstract}

Kata Kunci: bentuk istilah, sedekah gunung, makna, kearifan lokal, etnolinguistik

\begin{abstract}
This research discusses terms offerings of the alms ritual of Mount Merapi in Lencoh Village, District of Selo, Boyolali Regency. The purposes of this research are (1) to describe kind the terms offerings of the alms ritual of Mount Merapi in Lencoh Village, Boyolali; (2) to explain the lexical and cultural meaning of the terms offerings of the alms ritual of Mount Merapi in Lencoh Village, Boyolali; (3) to explain reflection of local wisdom in terms offerings of te alms ritual of Mount Merapi in Lencoh Village, Boyolali. This research uses an ethnolinguistic approach and a qualitative descriptive approach. Data in this research was collected using etnographic methods with observation and interview techniques. Analysis of the data in this research using distributional method, method of padan and ethnosains to the terms offerings alms ritual of mountain. The results showed: 1) the terms of offerings in the alms ritual of Mount Merapi consists of words and phrases; 2) the terms offerings of the almsritual of Mount Merapi classified based on lexical meaning and cultural meaning; and 3) local wisdom that found in the terms offerings of the alms ritual of Mount Merapi is cultural wisdom that acquired through life experience and or passed down from generation to generation as a guideline for activities.
\end{abstract}

Keywords: form of terms, alms of mountain, meaning, local wisdom, etnolinguistic

(C) 2019 Universitas Negeri Semarang p-ISSN 2252-6463 e-ISSN 2686-5408 


\section{PENDAHULUAN}

Bahasa merupakan suatu alat yang memiliki banyak fungsi, salah satunya sebagai alat yang digunakan untuk mempermudah komunikasi manusia. Lebih dari itu, bahasa juga dapat mencerminkan kebudayaan yang dimiliki suatu daerah. Rahyono (2009:77) menjelaskan mengenai hubungan antara bahasa dengan kebudayaan menggambarkan bahwa di saat bahasa digunakan dalam konteks komunikasi, bahasa terjalin dengan kebudayaan dalam cara yang kompleks. Melalui tuturan bahasa yang diungkapkan penutur bahasa dengan latar belakang budaya tertentu, maka budaya yang ada dalam lingkungan penutur tersebut dapat diidentifikasi.

Hubungan antara bahasa dengan budaya memiliki keterkaitan yang cukup erat. Bahasa menjadi produk budaya sekaligus alat untuk merepresentasikan kebudayaan dari masyarakat bahasa itu sendiri. Bahasa jika dilihat dari fungsinya merupakan suatu alat atau akses yang digunakan oleh manusia sebagai pelaku budaya untuk menunjukkan dan memperlihatkan bagaimana budaya mereka berwujud dan dapat dimaknai oleh orang lain. Pernyataan tersebut didukung dengan teori yang diungkapkan oleh Duranti (2000: 52) yang menyatakan bahwa seseorang tidak akan benar-benar memahami budaya milik orang lain tanpa memiliki akses langsung pada bahasanya. Singkatnya, tanpa memahami bahasa, orang tidak akan mampu memahami budaya milik orang lain.

Bahasa menjadi salah satu dari tujuh unsur kebudayaan yang merupakan komponen yang cukup penting. Bahasa berpengaruh terhadap perilaku manusia. Setiap daerah memiliki budayanya sendiri seperti, adat dan tradisi yang beragam. Desa Lencoh sebagai salah satu desa di wilayah Kecamatan Selo, Kabupaten Boyolali, memiliki tradisi yang dilestarikan hingga saat ini yakni sedekah Gunung Merapi.

Sedekah Gunung Merapi merupakan suatu tradisi ritual yang dilaksanakan setiap tahun pada bulan Sura atau tepatnya 1 Muharram dalam menyambut pergantian tahun baru Islam. Ritual tersebut dilaksanakan sebagai upaya selamatan atau meminta selamat kepada Tuhan agar dijauhkan dari marabahaya. Ritual sedekah Gunung Merapi berkaitan erat dengan hubungan antara manusia dengan alam. Masyarakat Desa Lencoh menyadari bahwa mereka tinggal di lereng utara Gunung Merapi yang dikenal sebagai gunung api teraktif. Sedekah gunung dilakukan secara khusus untuk meminta keselamatan dari bahaya yang ditimbulkan oleh Gunung Merapi dengan memberikan sesaji yang dilarung di puncak gunung, tepatnya di area Pasar Bubrah.

Sesaji menjadi item penting dalam setiap kegiatan ritual, dapat berupa makanan atau benda. Alwi (2002:979) menyatakan mengenai sesaji atau sering disebut sajen yang merupakan suatu makanan bisa berupa buah-buahan atau lain sebagainya yang disajikan kepada makhluk halus. Sesaji pada ritual sedekah gunung diperuntukkan untuk makhluk gaib yang mendiami Gunung Merapi.

Jenis sesaji yang ada dalam ritual sedekah gunung memiliki istilah-istilah yang digunakan untuk menyebutkan objek sesajinya baik berupa makanan atau selain makanan. Misalnya istilah gomok. Istilah gomok merujuk pada makanan yang terbuat dari ares 'bonggol pisang' yang dimasak dengan bumbu kemudian dibentuk sebesar kepalan tangan.

Mengingat tradisi Suran dengan menggelar ritual sedekah Gunung Merapi ini masih terus dilestarikan dan menjadi salah satu ritual penting yang tidak boleh ditinggalkan setiap pergantian tahun baru Islam, maka tentunya tradisi tersebut menyimpan makna dan manfaat yang penting bagi masyarakat. Ritual sedekah gunung terdapat banyak istilah yang dapat digali makna serta cerminan kearifan lokal masyarakat. Penelitian akan dikaji menggunakan sudut pandang etnolinguistik yang fokus pada hubungan bahasa dan kebudayaan suatu komunitas masyarakat.

\section{METODE PENELITIAN}

Pendekatan yang digunakan pada penelitian ini yaitu pendekatan etnolinguistik dan pendekatan deskriptif kualitatif. Data dalam penelitian berupa istilah-istilah yang digunakan dalam menyebutkan nama sesaji ritual sedekah Gunung Merapi, sedangkan sumber data pada penelitian ini bersumber dari hasil observasi di lapangan dan wawancara dengan narasumber. Data diperoleh dengan metode observasi dan wawancara. Setelah data diperoleh kemudian dianalisis menggunakan metode distribusional, metode padan, dan pendekatan 
etnosains untuk mengetahui cerminan kearifan lokal dalam ritual sedekah Gunung Merapi.

Metode distribusional alat penentunya adalah bahasa itu sendiri (Zaim, 2014:101). Metode distribusional digunakan untuk menganalisis bentuk istilah-istilah sesaji ritual sedekah Gunung Merapi sesuai dengan kategorinya apakah termasuk kata atau frasa. Metode padan digunakan untuk menganalisis makna dibalik istilah-istilah sesaji ritual sedekah gunung. Metode etnosains digunakan untuk menganalisis cerminan kearifan lokal dalam ritual sedekah Gunung Merapi, sehingga struktur suatu etnik, penduduk suatu kebudayaan yang tercermin dalam istilah, mengacu pada wujud benda, hal dan kegiatannya dapet diketahui. Data yang dipilih adalah data kognitif yang mencerminkan sesuatu yang ada di dalam kepala orang-orang yang diteliti Ahimsa (1985:110-111).

\section{HASIL DAN PEMBAHASAN}

\section{Istilah-Istilah Sesaji Ritual Sedekah Gunung Merapi di Desa Lencoh, Kecamatan Selo, Kabupaten Boyolali}

Berdasarkan hasil penelitian lapangan, ditemukan data sesaji yang diklasifikasikan dalam bentuk sesaji yang secara lingual berbentuk kata dan frasa.

\section{Bentuk Istilah-istilah Sesaji Ritual Sedekah Gunung Merapi}

Istilah sesaji ritual sedekah Gunung Merapi berbentuk kata dan frasa. Istilah sesaji berbentuk kata terdiri atas kata monomorfemis dan polimorfemis. Bentuk istilah sesaji berupa kata monomorfemis berkategori nomina, seperti pada istilah sesaji berupa makanan yakni gomok [gomo?]. Gomok [gomo?] merupakan bentuk kata dasar. Istilah tersebut dapat berdiri sendiri sebagai kata sehingga berdasarkan distribusinya termasuk kedalam morfem bebas. Berdasarkan jumlah morfemnya gomok [goms?] termasuk kata yang berbentuk monomorfemis karena terdiri dari satu morfem.

Bentuk kata polimorfemis terdapat pada istilah sesaji berupa makanan yakni gorengan [gorenan]. Istilah gorengan termasuk dalam golongan kata polimorfemis yang mengalami proses morfologis berupa afiksasi atau pengimbuhan. Hal tersebut karena gorengan berasal dari bentuk dasar verba goreng yang mendapatkan imbuhan berupa panambang atau akhiran -an. Bentuk verba goreng yang mendapatkan akhiran -an berubah menjadi bentuk kata yang berkategori nomina.

Bentuk kata polimorfemis berikutnya yakni bentuk istilah sesaji yang mengalami proses morfologis berupa pengulangan atau redulplikasi. Istilah yang ditemukan hanya terdapat satu termasuk sesaji berupa makanan yakni ancung-ancung [anconancon]. Istilah ancung-ancung mengalami pengulangan utuh tanpa perubahan bentuk vokal. Ancung-ancung termasuk dalam kelas kata kategori nomina. Proses reduplikasi istilah ancung-ancung terjadi pada perulangan utuh bentuk dasar ancung sehingga membentuk istilah ancung-ancung.

Bentuk kata polimorfemis pemajemukan atau komposisi terdapat pada istilah palawija [polowijo]. Palawija termasuk kata majemuk. Pemajemukan kata palawija dari kata pala+wija yang memiliki arti hasil bumi berupa umbi-umbian, kacang-kacangan, dan biji-bijian seperti, jagung. Palawija masuk dalam kelas kata nomina.

Bentuk istilah sesaji berikutnya yakni berbentuk frasa. Data istilah-istilah sesaji berbentuk frasa dianalisis dan diklasifikasikan dalam bentuk frasa berdasarkan distribusinya, frasa berdasarkan kategori, frasa berdasarkan satuan lingual unsurunsurnya, dan frasa berdasarkan kategori unsurunsurnya.

\section{Istilah-Istilah Sesaji Sedekah Gunung Merapi Berbentuk Frasa Berdasarkan Distribusinya}

Berdasarkan distribusinya istilah-istilah sesaji ritual sedekah Gunung Merapi yang berbentuk frasa ini termasuk ke dalam frasa endosentrik atributif. Contoh data yang ditemukan seperti pada istilah golong cilik [golon cill?]. Golong cilik termasuk frasa endosentrik atributif. Kata golong menjadi inti frasa memiliki kedudukan lebih tinggi, sedangkan kata cilik memiliki kedudukan sebagai unsur pelengkap atau atribut dari inti frasa. Dua kata yang tergabung menjadi satu frasa tersebut menghasilkan bentuk baru berupa frasa yang bertipe endosentrik atributif.

\section{Istilah-Istilah Sesaji Ritual Sedekah Gunung Merapi Berbentuk Frasa Berdasarkan Kategori Intinya}

Frasa berdasarkan kategori intinya dibedakan menjadi enam, yaitu frasa nominal, frasa verbal, frasa adjektifal, frasa numeralia, frasa 
adverbial, dan frasa preposisional. Hasil menunjukkan bahwa semua istilah-istilah sesaji ritual sedekah gunung ini berdasarkan kategori intinya berbentuk frasa nominal.

Berikut merupakan contoh hasil analisis data pada istilah endhas kebo [ənḍas kəbo]. Berdasarkan kategori intinya, istilah sesaji endhas kebo merupakan frasa nominal karena memiliki sifat nonpredikatif, dengan nomina sebagai intinya. Istilah sesaji endhas kebo merupakan bentuk frasa yang memiliki unsur inti pada kata endhas yang termasuk kategori kata nomina (N), sehingga frasa endhas kebo termasuk ke dalam jenis frasa nominal

\section{Istilah-Istilah Sesaji Ritual Sedekah Gunung Merapi Berbentuk Frasa Berdasarkan Satuan Lingual Unsur-unsurnya}

Struktur frasa dalam bahasa Jawa terdapat enam jenis, dilihat berdasarkan satuan lingual unsurunsurnya, yaitu: (1) kata+kata, (2) kata+frasa, (3) frasa+kata, (4) frasa+frasa, (5) kata+klausa, (6) frasa+klausa. Istilah-istilah sesaji ritual sedekah Gunung Merapi yang berbentuk frasa berdasarkan satuan lingual unsur-unsurnya memiliki tiga bentuk pola struktur frasa berupa (1) kata+kata, (2) kata+frasa, dan (3) frasa+ kata.

Istilah-istilah sesaji ritual sedekah Gunung Merapi yang berbentuk kata+kata contohnya gedhang setangkeb [gədan sətankəb]. Istilah sesaji ritual sedekah Gunung Merapi gedhang setangkeb berstruktur kata+kata yang terdiri atas kata gedhang dan kata setangkeb.

Istilah-istilah sesaji ritual sedekah Gunung Merapi yang berbentuk kata+frasa contonya berupa rokok djolali penthung [roko? djolali pențu]. Istilah sesaji ritual sedekah Gunung Merapi rokok djolali penthung berstruktur kata+frasa. Rokok berdiri sebagai kata $(\mathrm{K})$ sedangkan djolali penthung yang merupakan satu kesatuan, sebagai frasa.

Istilah-istilah sesaji ritual sedekah Gunung Merapi yang berbentuk frasa+kata contonya gedhang raja sajodho [gədan rojo sajoḍo]. Istilah sesaji ritual sedekah Gunung Merapi gedhang raja sajodho berstruktur frasa+kata. Gedhang raja berdiri sebagai frasa (F) sedangkan sajodho berdiri sebagai kata.

\section{Istilah-Istilah Sesaji Ritual Sedekah Gunung Merapi Berbentuk Frasa Berdasarkan Kategori Unsur-unsurnya}

Berdasarkan kategori unsur-unsurnya, istilah-istilah sesaji ritual sedekah Gunung Merapi di Desa Lencoh, Selo, Boyolali berbentuk $N+N, N+V$, $\mathrm{N}+\mathrm{Num}$, dan $\mathrm{N}+$ Adj. Contoh frasa berbentuk $\mathrm{N}+\mathrm{N}$ yakni brondong jagung [brondon jagon]. Istilah sesaji sedekah Gunung Merapi brondong jagung terdiri atas gabungan dari kata brondong yang termasuk dalam kelas kata nominal (N), dan kata jagung yang merupakan kelas kata nominal (N).

Frasa berbentuk N+V contohnya adalah jadah bakar [jadah bakar] Istilah sesaji sedekah Gunung Merapi jadah bakar terdiri atas gabungan dari kata jadah yang termasuk dalam kelas kata nominal (N), dan kata bakar yang merupakan kelas kata verba (V)

Bentuk frasa dari istilah-istilah sesaji yang ditemukan berikutnya berbentuk $\mathrm{N}+\mathrm{Num}$. Contoh data berupa tumpeng pitu [tumpən pitu] Istilah sesaji sedekah Gunung Merapi tumpeng pitu terdiri atas gabungan dari kata tumpeng yang termasuk dalam kelas kata nominal (N), dan kata pitu yang merupakan kelas kata numeralia (Num).

Bentuk frasa yang terakhir berdasarkan kategori unsur-unsurnya berupa $\mathrm{N}+$ adj. Contohnya, lombok abang [lombs? aban] Istilah sesaji sedekah Gunung Merapi lombok abang terdiri atas gabungan dari kata lombok yang termasuk dalam kelas kata nominal (N), dan kata abang yang merupakan kelas kata adjektifal (Adj).

\section{Makna Leksikal Istilah Sesaji Ritual Sedekah Gunung Merapi}

Hasil analisis makna leksikal mengenai istilah sesaji sedekah gunung akan dijabarkan berdasarkan bentuk fisik dari sesaji itu sendiri. Makna leksikal sesaji sedekah gunung sebagai contoh yang pertama yakni panggang buta [pangan buto]. Panggang buta merupakan salah satu bentuk sesaji sedekah gunung berupa makanan. Panggang buta merupakan istilah untuk makanan yang terbuat dari gembus yang diiris kotak-kotak kemudian ditusuk menggunakan tusuk ranting kayu dan dimasak dengan cara dipanggang. Panggang buta yang digunakan untuk sesaji sebanyak sajodho 'sepasang' dua buah. 
Makna leksikal sesaji ritual sedekah gunung lainnya adalah istilah endhas kebo[əndas kəbo]. Endhas kebo merupakan istilah sesaji berupa kepala kerbau. Kerbau yang digunakan untuk ritual sedekah gunung adalah kerbau jantan. Endhas kebo disajikan dalam keadaan mentah tanpa dimasak terlebih dahulu. Endhas kebo yang telah dipisahkan dari badannya dibalut dengan kain mori 'kain kafan' dan diletakkan dalam sanggan 'wadah dari bilah bambu dan papan kayu berbentuk persegi' agar memudahkan saat hendak membawa sesaji ke puncak merapi.

\section{Makna Kultural Istilah-istilah Sesaji Ritual Sedekah Gunung Merapi}

Makna kultural didefinisikan sebagai makna yang berkembang dalam suatu lingkup masyarakat tertentu. Makna kultural berkembang sesuai dengan pola perilaku masyarakat serta cara pandang mereka terhadap kehidupan. Makna kultural hanya dipahami oleh masyarakat yang memahami hidup di tempat mereka berada atau tempat mereka tinggal. Makna kultural istilah-istilah sesaji sedekah Gunung Merapi menggambarkan hubungan manusia dengan Tuhan, hubungan manusia dengan orang lain atau sesamanya, dan terakhir menggambarkan hubungan manusia dengan alam.

Istilah sesaji yang menggambarkan hubungan manusia dengan Tuhan seperti pada istilah tumpeng rasul [tumpən rasul]. Kata tumpeng memiliki makna tumindake sing lempeng 'berperilaku yang baik' jadi setiap elemen masyarakat diharapkan dapat berperilaku baik dan memiliki tujuan yang sama dalam hidup bermasyarakat. Kata rasul sebagai atribut kata tumpeng, memiliki makna bahwa umat manusia khususnya yang beragama Islam harus senantiasa mengikuti ajaran-ajaran yang dicontohkan oleh Nabi Muhammad sebagai rasul Allah. Tumpeng rasul berbeda dengan delapan tumpeng lainnya karena harus disajikan dalam keadaan nyanthang 'panas'. Apabila tumpeng rasul yang hendak disajikan sudah tidak panas, masyarakat percaya akan ada musibah yang menimpa orang-orang yang terlibat dalam mempersiapkan sesaji sedekah gunung.

Tumpeng rasul biasanya dihias dengan kertas berwarna emas yang digunakan untuk membalut bagian luar tumpeng. Selain untuk keperluan estetis, kertas berwarna emas dipilih karena Nabi Muhammad merupakan cahaya bagi umat manusia yang bersinar terang, sebagai pencerah bagi kehidupan umat manusia di dunia. Kertas berwarna emas yang digunakan untuk menutupi bagian luar tumpeng rasul juga berfungsi agar tumpeng tidak lekas dingin.

Makna kultural sesaji sedekah gunung yang menggambarkan hubungan manusia dengan orang lain terdapat dalam istilah tukon pasar [tukon pasar]. Tukon pasar menjadi salah satu sesaji yang ada di ritual sedekah gunung sebagai suatu lambang keberagaman hidup manusia. Tukon pasar diletakkan di atas gedhang setangkeb yang sudah ditata agar membentuk lingkaran sehingga ruang antara dua sisir pisang tersebut dapat digunakan untuk meletakkan makanan. Gedhang setangkeb sebagai simbol kesatuan karena terdiri dari dua sisir pisang yang digabung menjadi satu kesatuan untuk menjaga agar keberagaman yang ada di sekitarnya tidak terpisah. Masyarakat yang memiliki keberagaman sudah seharusnya bersatu dan saling menjaga satu dengan lainnya.

Makna kultural istilah sesaji sedekah Gunung Merapi yang menggambarkan hubungan manusia dengan alam terdapat pada istilah jadah bakar [jadah bakar], pohung bakar [pohon bakar], dan tela bakar [telo bakar]. Jadah bakar, tela bakar dan pohung bakar yang kesemuanya cara penyajiannya dengan dibakar, memiliki makna bahwa masyarakat Desa Lencoh yang tinggal di kawasan pegunungan yakni Gunung Merapi dan Gunung Merbabu tidak diperkenankan untuk melakukan pembakaran baik sampah maupun membakar tanaman kering di alam untuk menghindari adanya kebakaran hutan di area gunung. Segala bentuk sesaji yang cara penyajiannya dengan cara dibakar tersebut merupakan suatu simbol pengingat bahwa manusia harus bisa menahan diri untuk tidak berbuat sesuatu atau melakukan kegiatan yang dapat merusak alam.

\section{Kearifan Lokal dalam Istilah-istilah Sesaji Ritual Sedekah Gunung Merapi}

Cerminan kearifan lokal yang muncul pada istilah-istilah sesaji ritual sedekah Gunug Merapi merupakan kearifan yang sifatnya sudah turuntemurun ada dalam komunitas masyarakat Desa Lencoh sebagai pemilik tradisi. Kearifan yang muncul pada istilah-istilah sesaji sedekah gunung ini dianalisis sesuai dengan pola pikir masyarakat dalam memandang sesaji sebagai suatu simbol tradisi yang di dalamnya mengandung maksud tertentu, dan menjadi interpretasi bagaimana sistem dalam 
masyarakat itu sendiri yakni warga Desa Lencoh, Kecamatan Selo, Kabupaten Boyolali berwujud.

Kearifan lokal yang tercermin pada istilahistilah sesaji ritual sedekah Gunung Merapi salah satunya berupa penghormatan kepada leluhur yang tercermin dalam istilah sesaji rokok klobot, rokok djolali penthung, rokok gudhang garam merah, dan rokok linting. Rokok yang disajikan dalam ritual sedekah Gunung Merapi memiliki kriteria khusus yakni dipilih rokok yang paling tua, atau paling awal dikenal dan dikonsumsi olah para pendahulu mereka pada zaman dahulu. Rokok-rokok tersebut merupakan rokok pilihan karena paling disenangi oleh para leluhur. Rokok klobot dan rokok linting merupakan dua jenis rokok yang paling banyak dikonsumsi leluhur pada masanya karena bisa dibuat sendiri tanpa harus membeli, dan masa konsumsinya cenderung lebih panjang dibandingkan rokok buatan pabrik.

Kebiasaan para leluhur dalam mengonsumsi rokok-rokok yang sudah jarang dikonsumsi pada saat ini, mendorong warga Desa Lencoh untuk tetap mempertahankan adat, dengan tidak mengganti rokok-rokok yang menjadi kesenangan para leluhurnya. Mereka percaya bahwa menghormati orang tua atau para leluhur merupakan salah satu upaya untuk memperoleh berkah pangestu sehingga akan memberikan dampak baik terhadap kegiatan yang mereka kerjakan.

Kearifan lokal yang juga tercermin pada istilah-istilah sesaji sedekah gunung yakni berupa kearifan religius yang tercermin pada istilah tumpeng rasul. Tumpeng rasul merupakan simbol representasi masyarakat Desa Lencoh yang beragama, artinya mereka menganut suatu keyakinan masing-masing. Mayoritas warga Desa Lencoh menganut agama Islam sehingga istilah sesaji yang digunakan menggunakan istilah tumpeng rasul.

Hubungan istilah sesaji tumpeng rasul dengan mayoritas warga Desa Lencoh adalah kata tumpeng dalam bahasa Jawa merupakan sebuah singkatan dari beberapa kata yakni tumindak sing lempeng 'bertindak dengan yakin' artinya setiap manusia hendaknya bertindak atau melakukan tindakan dengan penuh keyakinan terhadap Tuhan yang mahakuasa. Kata rasul sebagai atribut kata tumpeng, merujuk pada rasulullah yakni Nabi Muhammad sebagai utusan Allah di bumi untuk memberikan ajaran-ajaran kebajikan bagi seluruh umat manusia. Istilah tumpeng rasul mencerminkan kearifan religius di mana masyarakat menghormati sosok Nabi Muhammad sebagai rasul Allah.

\section{SIMPULAN}

Berdasarkan hasil analisis data yang telah diuraikan dapat disimpulkan bahwa pertama, istilahistilah sesaji ritual sedekah Gunung Merapi berupa kata dan frasa. Istilah sesaji berupa kata diklasifikasikan berdasarkan proses morfologis di antaranya yaitu pengimbuhan (afiksasi), reduplikasi (pengulangan), dan pemajemukan atau komposisi. Bentuk istilah sesaji berupa frasa yang ditemukan diklasifikan berdasarkan distribusi, kategori, berdasarkan satuan lingual unsur-unsurnya, dan berdasarkan kategori unsur-unsurnya. Kedua, istilahistilah sesaji dalam ritual sedekah gunung memiliki makna.

Makna diklasifikasikan berdasarkan makna leksikal dan makna kultural. Makna kultural yang ditemukan berdasarkan pemaknaan terhadap masingmasing bentuk istilah sesaji sesuai dengan pemahaman dan kepercayaan warga Desa Lencoh dalam memaknai simbol sesaji ritual sedekah Gunung Merapi.

Ketiga, kearifan lokal yang ditemukan dalam ritual sedekah gunung merupakan kearifan kultural yang diperoleh dari pengalaman hidup tokoh masyarakat dan berdasarkan interpretasi ajaran leluhur baik berupa ajaran agama, pengetahuan, budaya dan sebagainya.

\section{SARAN}

Penelitian mengenai istilah-istilah sesaji ritual sedekah gunung di Desa Lencoh, Kabupaten Boyolali ini bisa digunakan sebagai media informasi terkait bentuk, makna, dan keraifan lokal apa saja yang tedapat dalam ritual tersebut dilihat dari aspek sesaji yang digunakan. Selain itu penelitian ini dapat dijadikan sebagai referensi untuk mengembangkan penelitian dengan studi etnolinguistik terkait dengan objek kajian istilah-istilah sesaji dalam upacara ritual tradisional Jawa di masa mendatang bagi penelitian selanjutnya. Saran untuk pemerintah Kabupaten Boyolali diharapkan dapat terus mendukung pelestarian berbagai tradisi daerah di wilayah Kabupaten Boyolali seperti dukungan yang telah diberikan pada ritual sedekah Gunung Merapi di Desa Lencoh. 
Suci Makrifah, Nur Fateah/Sutasoma 7 (2) (2019)

\section{DAFTAR PUSTAKA}

Ahimsa-Putra. 1985. Etnosains dan Etnometodologi: Sebuah Perbandingan. Masyarakat Indonesia Edisi Tahun XII (2): 103-133.

Alwi, Hasan. 2002. Kamus Besar Bahasa Indonesia. Jakarta: Balai Pustaka

Duranti, Alesandro. 2000. Linguistic Anthropology. New York: Cambrige University Press.

Rahyono, FX. 2009. Kearifan Budaya dalam Kata. Jakarta: Wedatama Widya Sastra.

Sudaryanto. 1993. Metode Dan Aneka Teknik Analisis Bahasa Pengantar Penelitian Wahana Kebudayaan secara Linguistik. Yogyakarta: Duta Wacana University Press

Zaim, M. 2014. Metode Penelitian Bahasa: Pendekatan Struktural. Padang: Sukabina Press Padang 